\title{
The application of FORMOSAT-2 high-temporal- and high-spatial resolution imagery for monitoring open straw burning and carbon emission detection
}

\author{
C.-C. Liu ${ }^{1,2}$, P.-Y. Tseng ${ }^{1}$, and C.-Y. Chen ${ }^{3}$ \\ ${ }^{1}$ Department of Earth Sciences, National Cheng Kung University, 701 Tainan, Taiwan \\ ${ }^{2}$ Global Earth Observation and Data Analysis Center, National Cheng Kung University, 701 Tainan, Taiwan \\ ${ }^{3}$ Department and Graduate School of Computer Science, National Pingtung University of Education, No. 4-18, \\ Ming Shen Rd., Pingtung 90003, Taiwan \\ Correspondence to: C.-Y. Chen (cyc@ mail.npue.edu.tw)
}

Received: 6 August 2012 - Published in Nat. Hazards Earth Syst. Sci. Discuss.: -

Revised: 10 December 2012 - Accepted: 17 January 2013 - Published: 6 March 2013

\begin{abstract}
Rice is produced in more than 95 countries worldwide and is a staple food for over half of the world's population. Rice is also a major food crop of Taiwan. There are numerous rice crops planted on the western plains of Taiwan, and, after the harvest season, the left-over straw is often burned on-site. The air pollutants from the burning emissions include $\mathrm{CO}_{2}, \mathrm{CO}, \mathrm{CH}_{4}$ and other suspended particles, most of these being the greenhouse gases which cause global climate change. In this study FORMOSAT- 2 satellite images and ground-truth data from 2008 and 2009 are used to conduct supervised classification and calculate the extent of the straw burning areas. It was found that $10 \%$ of the paddies in the study area were burned after harvest during this 2-yr period. On this pro rata basis, we calculated the overall carbon emissions from the burning of the straw. The findings showed that these few farmers produced up to 34000 tons of carbon emissions in 2008, and 40000 tons in 2009. The study results indicate that remotely sensed images can be used to efficiently evaluate the important characteristics for carbon emission detection. It also provides quantitative results that are relevant to tracking sources of transport pollution, postharvest burning, and Asian dust in Taiwan.
\end{abstract}

\section{Introduction}

Economic growth in East Asia including Korea, China and Japan has led to a rapid increase in the abundance of atmospheric aerosols over the past few decades (Akimoto, 2003;
Streets et al., 2003). The transport of aerosols from the Asian continent can be observed from satellite observations (Kim et al., 2006; Lee et al., 2006), and has shown enhancement of the aerosol optical depth over the Yellow Sea. The fine mass concentration of particulate matter $\left(\mathrm{PM}_{2.5}\right)$ has been measured at background sites located off the Korean peninsula, such as Taean, Kanghwa and Gosan. However, these sites have relatively cleaner air with less influence from local pollution (He et al., 2003; Lee et al., 2007). Studies have occasionally found $\mathrm{PM}_{2.5}$ mass concentrations exceeding the US NAAQS annual $\mathrm{PM}_{2.5}$ standard due to the influence of the long-range transport of aerosols from the Asian continent. The capabilities of recent satellites now provide an unprecedented opportunity to observe and monitor the dynamics of the earth's surface simultaneously from numerous perspectives (White, 1976; Kim et al., 2001; DeBell et al., 2006; Malm and Hand, 2007; Pitchford et al., 2007; Jung et al., 2009a) as well as monitor the effect of radiative forcing by the haze (Charlson et al., 1992; Haywood and Shine, 1995; Ramanathan et al., 2001; Yoon and Kim, 2006). More currently, Chang et al. (2012) proposed an innovative classification tool to classify high-resolution imagery taken by FORMOSAT-2 (FS-2), with the intention to map burned areas of rice paddy fields during harvest season. They provide visualized and accurate estimations for rice straw open burning in Taiwan.

The technique of remote sensing provides a twodimensional synoptic view with high spatial resolution. This method can be used to observe emissions from burning over 


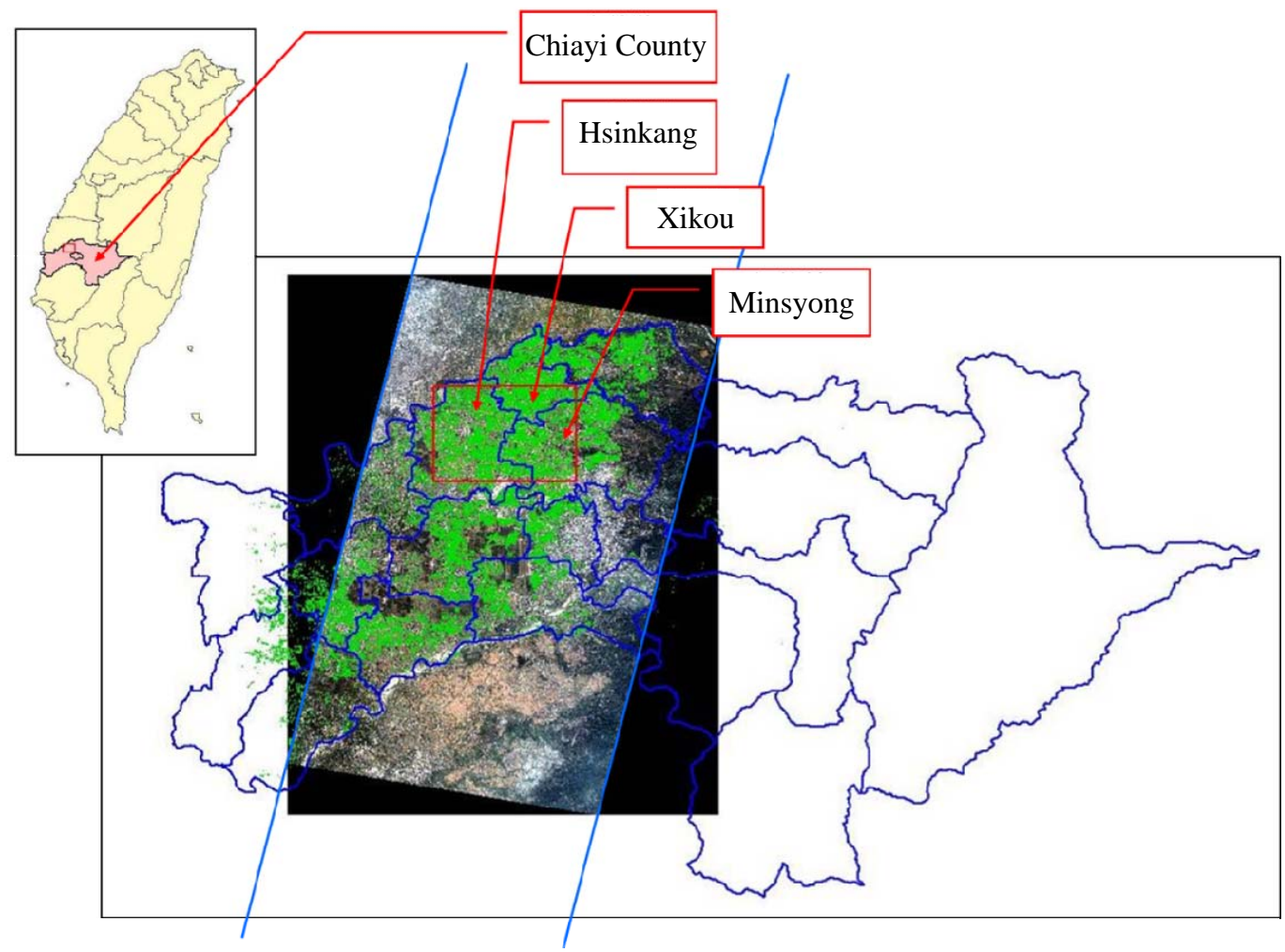

Fig. 1. Location of rice paddy areas in the Hsinkang, Xikou and Minsyong townships in Chiayi County.

long periods of time, even at isolated locations. After the rice harvest in Taiwan, the left-over straw is often burned on-site. The air pollutants produced by the burning emissions (such as PM, CO, NOx) can cause serious environmental pollution and poor air quality. In addition, the burning of straw near roadsides in Taiwan can lead to traffic safety concerns due to poor visibility. There is also an issue related to global environmental change. It is commonly accepted that warming results from large amounts of greenhouse gas emissions. According to the International Energy Agency (IEA)/OECD, the total amount of $\mathrm{CO}_{2}$ emissions in Taiwan in 2008 was 264.29 million tons, accounting for $0.9 \%$ of total global emissions. This meant that it was 22nd in global ranking, with per capita emissions of 11.53 tons, which was more than Japan, Korea and the OECD average, the 17th in the global ranking. Although the primary source of emissions is mainly from heavy industry, the burning of straw did result in regional air pollution and dumped large amounts of greenhouse gases into the atmosphere.

Here, we present a general overview of variations, and develop a suitable remote sensing method to carry out a wide range of image capture and data analysis as well as enhance the accuracy of the information acquired. Satellite images acquired from FORMOSAT-2 have high spatial and temporal and multi-spectral features, and can be used to carry out large-scale regional monitoring for image capture in Taiwan area, so it is one of the main tools used in this study. Although the spatial resolution is $2 \mathrm{~m}$, it still requires manpower to collect ground truths and validate the classified results. In order to improve the accuracy of determination and avoid climatic factors, we also used high spatial resolution photographs from unmanned aerial vehicles (UAV) to provide an alternative source of ground truth. Therefore, the manual interpretation from UAV aerial photos presents evidence confirming the accuracy of satellite images for conducting environmental monitoring. With this method the goal is to achieve high efficiency and accuracy. The methodology and data collections are same as in Chang et al. (2012) as well as the study area.

\section{Study area}

Chiayi County is located on the Chianan Plain of southwestern Taiwan. It is characterized by flat and open terrain, suitable for rice paddies. The main agricultural crop in this area is rice, making Chiayi County one of the top five rice producing counties in Taiwan. The rice growing area is also close to densely populated areas in the township and has a highway running through it. Many local people complain about the poor air quality due to the open air burning of the rice straw after the harvest. We used the exact geographic coordinates of paddy field burning obtained 


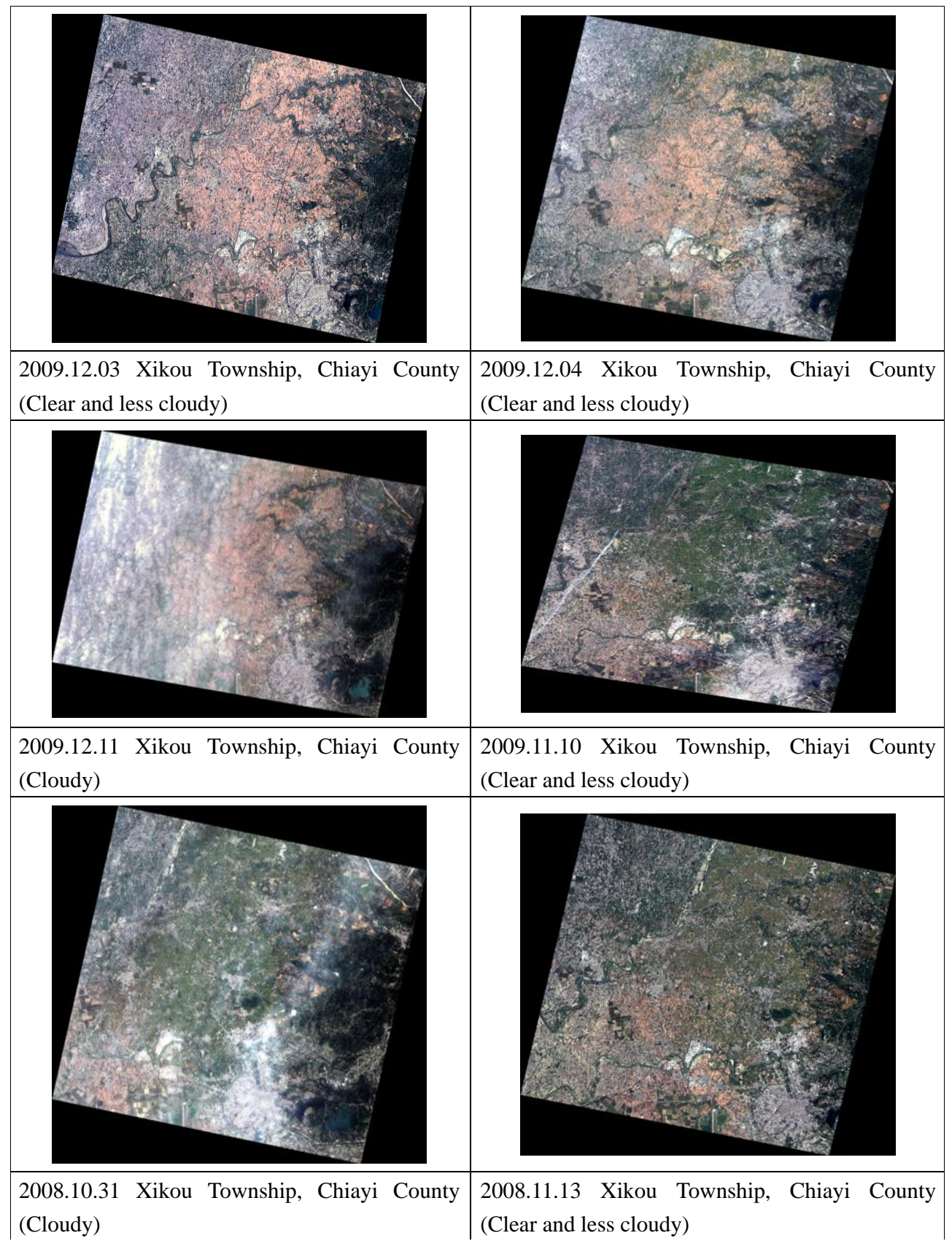

Fig. 2. Satellite image processing before and after the harvest in 2008 and 2009 in Xikou Township, Chiayi County.

from a site-inspection conducted by the Environmental Protection Bureau of Chiayi County in 2009 as training data for classification, and then on the basis of these sites plot the extent of agricultural land. The main locations are Hsinkang, Xikou Township and Minsyong Township in Chiayi County in southwest Taiwan. The green markers in the satellite images show the distribution of the rice paddy areas (Fig. 1).

\section{Data collection}

The selected study area included the surroundings of Xikou Township in Chiayi County (Fig. 1). Classification of the area for this study was conducted using intensive images acquired by FORMOSAT- 2 with its high re-visit incidence to the study areas during the rice harvest of 2008 and 2009. To sum up, there were effective images obtained for four periods before and after the harvest in 2008, and for six periods in 2009 (Fig. 2). 
Table 1. Statistics for classification of study area.

\begin{tabular}{llllll}
\hline Date & $\begin{array}{l}\text { Harvested Area } \\
\text { (Hectares) }\end{array}$ & $\begin{array}{l}\text { Burnt Areas } \\
\text { (Hectares) }\end{array}$ & $\begin{array}{l}\text { Areas Not } \\
\text { Harvested } \\
\text { (Hectares) }\end{array}$ & $\begin{array}{l}\text { Total Classified } \\
\text { Area (Hectares) }\end{array}$ & $\begin{array}{l}\text { Proportion of } \\
\text { Burning }\end{array}$ \\
\hline 4 December 2009 & 2429.75 & 493.65 & 1365.29 & 4288.69 & $11.51 \%$ \\
3 December 2008 & 1998.09 & 382.41 & 1461.64 & 3842.14 & $9.95 \%$ \\
\hline
\end{tabular}

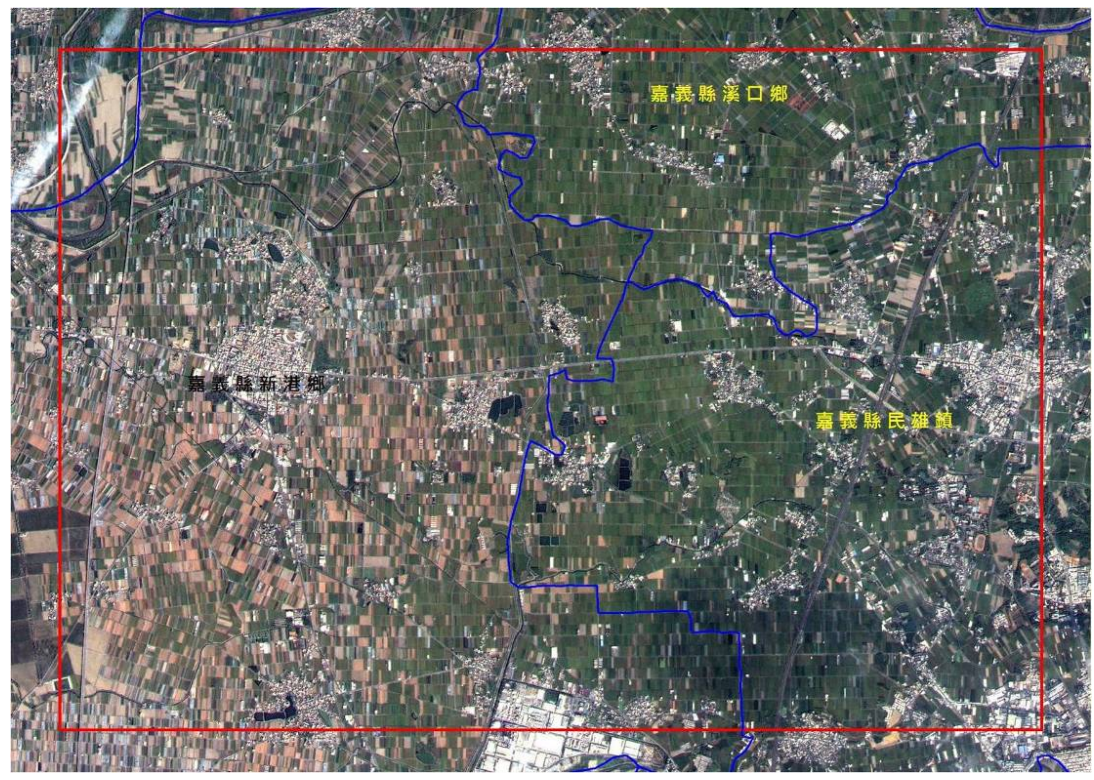

Fig. 3. Study area (Xikou Township) before the harvest.

The image selection rule was made before the rice harvest for the same area and the post images were orthorectified; the selected dates were 13 November 2008 and 3 December, 10 November 2009 (Fig. 3) and 3 December (Fig. 4). We also use the results of manual ground inspection to conduct GPS geolocation for the marking of burned areas (Fig. 5).

\section{Calculation of carbon emissions}

According to the study of Gadde et al. (2007), the straw to grain ratio (SGR) is 0.75 , which is in line with statistics for the Taiwan's annual rice production obtained from the Agriculture and Food Agency of the Council of Agriculture (COA). From these data we can calculate back to find the total amount of left-over rice straw per rice harvest (Gadde et al., 2009).

- $Q_{\mathrm{SSFB}}:$ Amount of straw burned per period

- $P_{\mathrm{RR}}$ : Total rice production per period

- SGR: Straw to grain ratio -0.75

- $Q_{\mathrm{SFB}}:$ Burned proportion of rice fields (\%)
Gadde et al. (2009) also surveyed former studies to determine the various gases and particulates generated when the straw is burnt, as shown in Table 2.

Based on $E_{a}=Q_{\mathrm{SSFB}} \times \mathrm{EF}_{a} \times f_{\mathrm{Co}}$ (Formula 1) (Gadde et al., 2009), the following can be defined:

- $E_{a}$ : Total gas emissions;

$-\mathrm{EF}_{a}$ : Emission factors of various gases from burning rice straw; and

- $f_{\mathrm{Co}}$ : Burning factor, 0.80 (burnt proportion).

After carrying out a calculation based the above information, we obtained the total carbon emissions from the open burning of rice straw in the second crop area for 2008 and 2009, as shown in Table 4.

\section{Conclusions}

The study results show that this supervised classification method could be used to make the correct classification of the extent of the straw burning area from multispectral FORMOSAT-2 images and other data for the training area after completing orthorectification. For example, for 2009, 


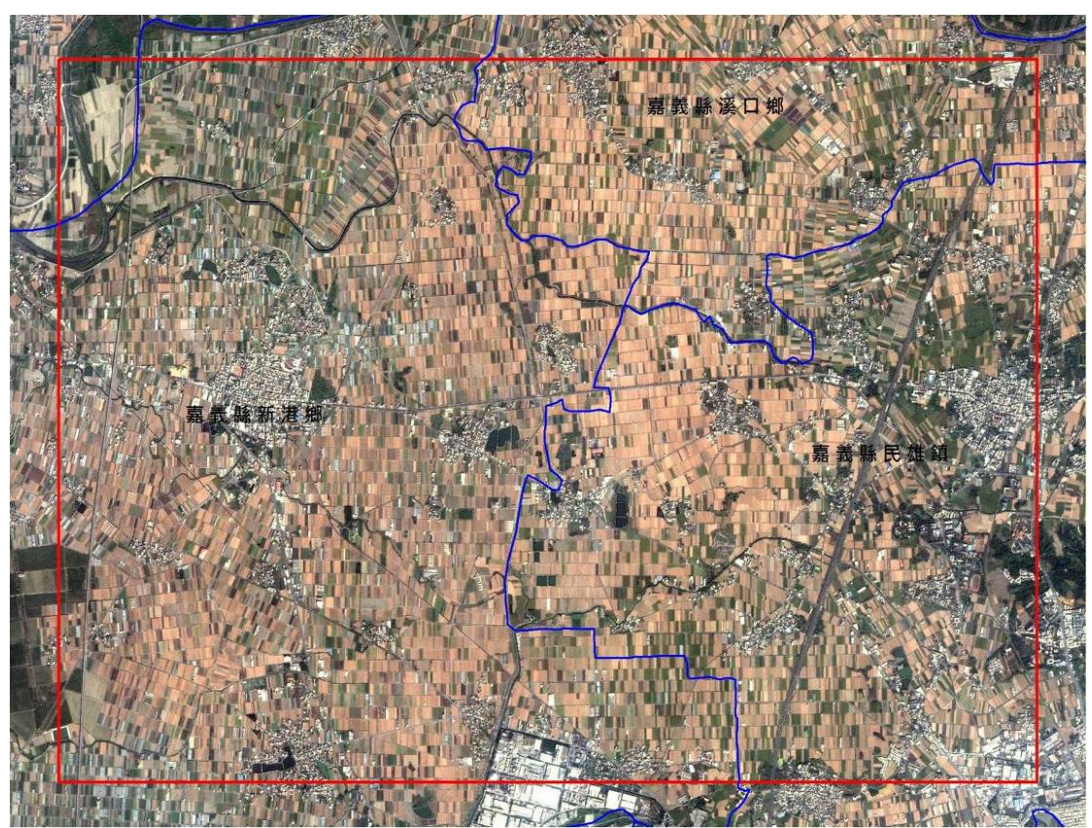

Fig. 4. Study area (Xikou Township) after the harvest.

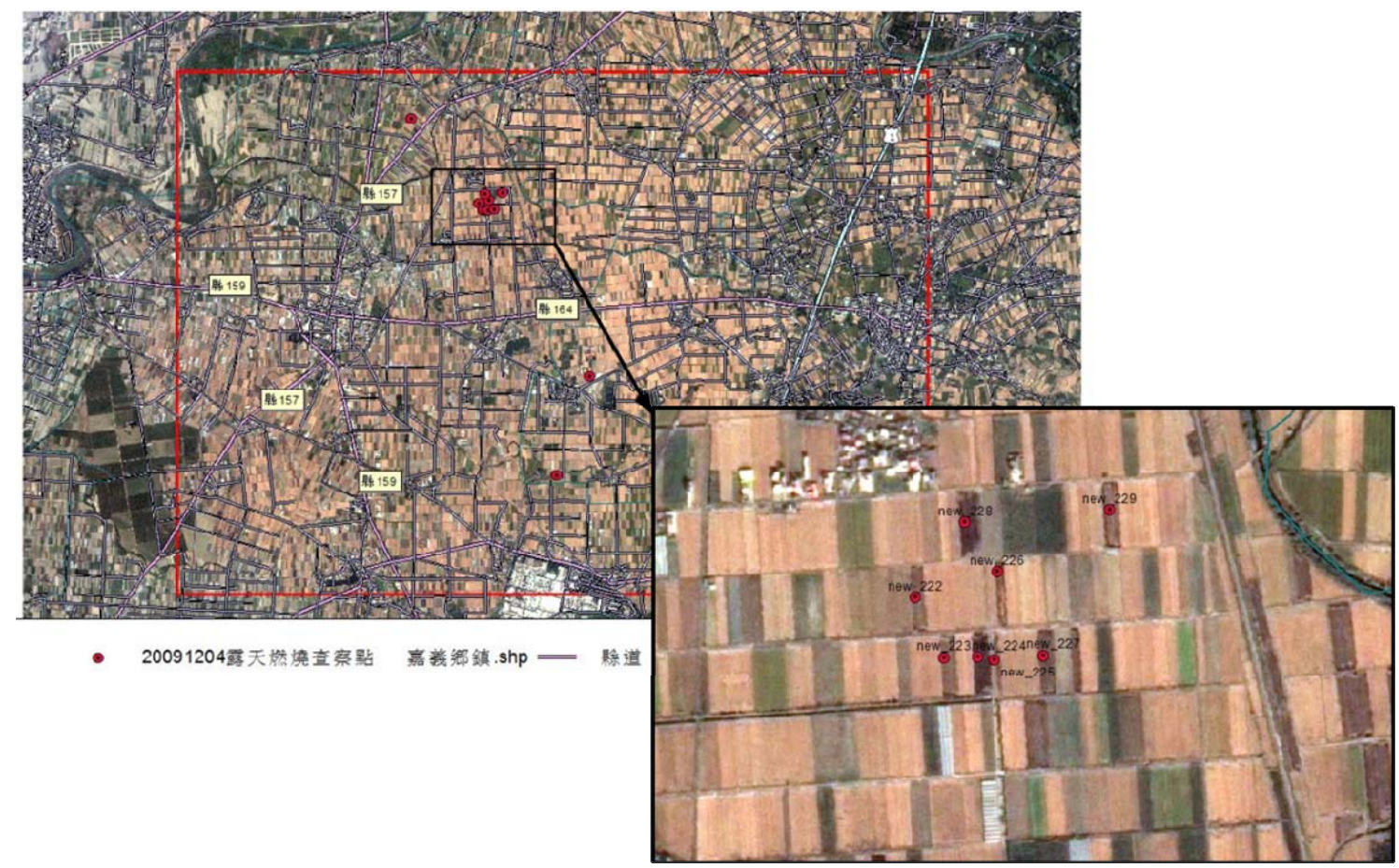

Fig. 5. Study area (Xikou Township).

we took the partial ground truths and validated the classified results from the manual audit as the basis of supervised classification, and used the rest for independent checkpoints. We successfully classified 14 checkpoints out of 16 . Although the remaining two were classified as unburned areas, there were still burn marks on adjacent farmlands. We suppose that this might have been the result of the tolerance of the handheld GPS when collecting the seismic data, or that the recording staff had not actually entered the paddy fields. The accuracy obtained by re-examining the classification results was $87.5 \%$, which proves that this method is reliable. During the second rice harvests in 2008 and 2009, open straw 
Table 2. Emission factors (EFs) (Gaddle et al., 2009).

Summary of EFs specific to rice straw open burning along with their references.

\begin{tabular}{lllll} 
Name of pollutant & Unit & $\begin{array}{l}\mathrm{EF} \\
\text { (open } \\
\text { burning) }\end{array}$ & Reference & Remarks \\
\hline $\mathrm{CO}_{2}$ & $\mathrm{~g} \mathrm{~kg}^{-1} \mathrm{dm}^{2}$ & 1460 & (Jenkins and Bhatnagar, 1991) & $\begin{array}{l}\text { The EF is specific to open field burning } \\
\text { of rice straw. }\end{array}$ \\
\hline $\mathrm{CH}_{4}$ & $\mathrm{~g} \mathrm{~kg}^{-1}$ dry fuel & 1.2 & (US EPA, 1992) & $\begin{array}{l}\text { The EF is sourced from the AP-42 } \\
\text { database developed by the US } \\
\text { Environmental protection Agency } \\
\text { (US EPA) for rice straw. }\end{array}$
\end{tabular}

$\mathrm{N}_{2} \mathrm{O} \quad \mathrm{g} \mathrm{kg}^{-1}$ dry fuel $\quad 0.07 \quad$ (Andreae and Merlet, 2001) It is proven that $\mathrm{N}_{2} \mathrm{O}$ is one of the
compounds being emitted from biomass burning. It is also identified as one of the pollutants emitted from open field burning of rice straw (Ogawa and Yoshida, 2005). As a specific EF for rice straw is not available, an average EF for agricultural residue burning was considered instead in this study

$\begin{array}{llll}\mathrm{CO} & \mathrm{g} \mathrm{kg}^{-1} \mathrm{dm} & 34.7 & \text { (Kadam et al., 2000) These are the latest EF data that are }\end{array}$
available for rice straw.

Gupta et al. (2004) had also mentioned an EF, but sourced from a paper published in 1991 by Jenkins and Bhatnagar (1991). Other references confirm the EF considered in the present study, i.e. Ortiz de Z'arate et al. (2000) and Badarinath et al. (2006)

\begin{tabular}{lllll}
\hline NMHC & $\mathrm{g} \mathrm{kg}^{-1}$ & 4 & (US EPA, 1992) & $\begin{array}{l}\text { This EF is sourced from the } \\
\text { AP-42 database. }\end{array}$ \\
\hline NOX & $\mathrm{g} \mathrm{kg}^{-1} \mathrm{dml}$ & 3.1 & (Kadam et al., 2000) & $\begin{array}{l}\text { This EF is for cereal waste } \\
\text { burning (Ortiz de Z'arate et al.,2000) }\end{array}$ \\
\hline $\mathrm{SO}_{2}$ & $\mathrm{~g} \mathrm{~kg}^{-1}$ & 2 & (Jenkins and Bhatnagar, 1991) & $\begin{array}{l}\text { This EF is in contradiction with another } \\
\text { EF for general crop residue burning re- } \\
\text { ported by Habib et al. (2004). It is due } \\
\text { to disparity in the straw sulphur content. }\end{array}$ \\
& & &
\end{tabular}

\begin{tabular}{lllll}
\hline $\begin{array}{l}\text { Total particulate } \\
\text { matter (TPM) }\end{array}$ & $\mathrm{g} \mathrm{kg}^{-1}$ dry fuel & 13 & Ortiz de Z'arate et al.(2000) & $\begin{array}{l}\text { No specific reference for rice straw. } \\
\text { This EF is specific to TPM for cereal } \\
\text { waste and is consistent with EF from } \\
\text { Andreae and Merlet }(2001) .\end{array}$ \\
\hline $\begin{array}{l}\text { Fine particulate } \\
\text { matter }\left(\mathrm{PM}_{2.5}\right)\end{array}$ & $\mathrm{g} \mathrm{kg}^{-1} \mathrm{dm}$ & 12.95 & (Hays et al., 2005) & $\begin{array}{l}\text { This EF is specific for open field } \\
\text { burning of rice straw. }\end{array}$ \\
\hline $\mathrm{PM}_{10}$ & $\mathrm{~g} \mathrm{~kg}^{-1}$ dry fuel & 3.7 & (Kadam et al., 2000) & $\begin{array}{l}\text { This EF is matched other data found } \\
\text { in the literature including Badarinath et } \\
\text { al. (2006) and is specific to rice straw }\end{array}$ \\
\hline
\end{tabular}

\begin{tabular}{lllll}
\hline $\begin{array}{l}\text { Polycyclic aromatic } \\
\text { hydrocarbons (PAHs) }\end{array}$ & $\mathrm{mg} \mathrm{kg}^{-1}$ dry fuel & 18.62 & (Keshtkar and Ashbaugh, 2007) & This EF is specific to rice straw alone. \\
\hline $\begin{array}{l}\text { Polychlorinated } \\
\text { dioxins and } \\
\text { furans (PCDD/F) }\end{array}$ & $\begin{array}{l}\mathrm{Ng} \\
\text { international } \\
\text { toxic } \\
\text { equivalency } \\
\text { (I-TEQ)/kg }\end{array}$ & 0.5 & (Gullett and Touati, 2003) & $\begin{array}{l}\text { This EF is specific to rice straw alone } \\
\text { and is indicated in other studies } \\
\text { as well (Shiha et al., 2008) }\end{array}$ \\
\hline
\end{tabular}

$\mathrm{Dm}^{*}=$ material 
Table 3. The exhaust gases from the open burning of rice straw associated with carbon emissions (Gaddle et al., 2009).

\begin{tabular}{llll}
\hline Name of pollutant & Unit & EF (open burning) & Reference \\
\hline $\mathrm{CO}_{2}$ & $\mathrm{~g} \mathrm{~kg}^{-1} \mathrm{dm}^{*}$ & 1460 & (Jenkins and Bhatnagar, 1991) \\
$\mathrm{CH}_{4}$ & $\mathrm{~g} \mathrm{~kg}^{-1}$ dry fuel & 1.2 & (US EPA, 1992) \\
$\mathrm{CO}$ & $\mathrm{g} \mathrm{kg}^{-1} \mathrm{dm}$ & 34.7 & (Kadam et al., 2000) \\
\hline
\end{tabular}

Table 4. Estimation of carbon emissions from open rice straw burning within the study area (Xikou Township) during $2008-2009$.

\begin{tabular}{lllllllll}
\hline Year & $\begin{array}{l}\text { Rice yield } \\
\text { per hectare } \\
\text { of the } \\
\text { second } \\
\text { crop }\end{array}$ & $\begin{array}{l}\text { Study area } \\
\text { (hectare) }\end{array}$ & $\begin{array}{l}\text { Burnt } \\
\text { proportion } \\
\%\end{array}$ & $\begin{array}{l}\text { Amount of } \\
\text { straw burnt } \\
\text { (tons) }\end{array}$ & $\begin{array}{l}\mathrm{CO}_{2} \\
\text { Emission } \\
\text { (tons) }\end{array}$ & $\begin{array}{l}\mathrm{CO} \\
\text { Emission } \\
\text { (tons) }\end{array}$ & $\begin{array}{l}\mathrm{CH}_{4} \\
\text { Emission } \\
\text { (tons) }\end{array}$ & $\begin{array}{l}\mathrm{C} \\
\text { Total } \\
\text { Emission }\end{array}$ \\
\hline 2009 & 4019 & 4288.69 & 11.51 & 1487.98 & 1737.9 & 41.3 & 3.52 & 494.33 \\
\hline 2008 & 3427 & 3842.14 & 9.95 & 982.88 & 1148.0 & 27.2 & 3.52 & 327.42 \\
\hline
\end{tabular}

burning areas accounted for $10 \%$ of the total paddy field area, which is several times more than the $2 \%$ reported by agricultural authorities from self-gathered statistics. In addition, people in Yunlin, Chiayi and Tainan generally consider the open burning of rice straw the main factor behind poor air quality. The study determined that more than $10 \%$ of the total paddy area was burnt, which is more in line with the current actual situation. The high spatial resolution and daily re-visit incidence of the images from FORMOSAT- 2 could provide responsible governmental units with prompt and accurate information about the open burning of rice straw so that appropriate measures can be taken to remedy the situation.

In Asia countries, rice straw open-field burning is practiced for the particulate matter (PM) and PAH concentrations during rice straw open burning. Rice straw open burning has been one of the important sources impacting air quality in Taiwan recently. The open burning significantly impacts visibility, and particulate matter produced by rice straw open burning impacts air quality in closed-up surroundings. Chang et al. (2012) verified the field data, with an overall accuracy of $87 \%$ for distinguishing among the 6 cover types of rice paddies, indicating that $27.3 \%$ of the paddies within the research area were openly burned. However, the valuable results concluded that the innovative approach is helpful to engineers for utilizing the remote sensing resources and achieving better efficacy on environmental commitments, environmental strategies, and environmental protection both more effectively and efficiently. Moreover, the main contribution of present study is to provide resultant data collected in 2008-2009 for understanding open straw burning and carbon emission detection. Future observations and data analysis are already planned in order to evaluate the characteristics of organic compounds in the biomass open burning, and its impact on the human biological community.
Acknowledgements. We are appreciative of the financial support in the form of research grants from the National Science Council, Republic of China to Cheng-Chien Liu (grant nos. NSC 1012627-B-006-013 and NSC 101-2611-M-006-002). The authors are also most grateful for the kind assistance of Professor Luca Ferraris, Handling Editor of Natural Hazards and Earth System Sciences, and for the constructive suggestions from the anonymous reviewers, all of which have led to the making of several corrections and have greatly improved the presentation of this paper.

Edited by: L. Ferraris

Reviewed by: two anonymous referees

\section{References}

Akimoto, H.: Global air quality and pollution, Science, 302, 17161719, doi:10.1126/science.1092666, 2003.

Andreae, M. O. and Merlet, P.: Emission of trace gases and aerosols from biomass burning, Global Biogeochem. Cy., 15, 955-966, 2001.

Chang, C. H., Liu, C. C., and Tseng, P. Y.: Emissions inventory for rice straw open burning in Taiwan based on burned area classification and mapping using FORMOSAT-2 satellite imagery, Aerosol Air Quality Res., doi:10.4209/aaqr.2012.06.0150, 2012.

Charlson, R. J., Schwartz, S. E., Hales, J. M., Cess, R. D., Coakley, J. A. Jr., Hansen, J. E., and Hofmann, D. J.: Climate forcing by anthropogenic aerosols, Science, 255, 423-430, doi:10.1126/science.255.5043.423, 1992.

DeBell, L. J., Gebhart, K. A., Hand, J. L., Malm, W. C., Pitchford, M. L., Schichtel, B. A., and White, W. H.: Spatial and seasonal patterns and temporal variability of haze and its constituents in the United States, Rep. IV, Coop. Inst. for Res. in the Atmos., Fort Collins, Colo., http://vista.cira.colostate.edu/improve/ Publications/Reports/2000/2000.htm., 2006.

Gadde, B., Menke, C., and Wassmann, R.: Possible energy utilization of rice straw in Thailand: seasonal and spatial variations in straw availability as well as potential reduction in greenhouse 
gas emissions, GMSARN International Conference on Sustainable Development: Challenges and Opportunities for GMS, GMSARN Secretariat, AIT, Pattaya, Thailand, 2007.

Gadde, B., Bonnet, S., Menke, C., and Garivait, S.: Air pollutant emissions from rice straw open field burning in India, Thailand and the Philippines, Environmental, 157, 1554-1558, 2009.

Gullett, B. and Touati, A.: PCDD/F emissions from burning wheat and rice field residue, Atmos. Environ., 37, 4893-4899, 2003.

Hays, M. D., Fine, P. M., Geron, C. D., Kleeman, M. J., and Gullett, B. K.: Open burning of agricultural biomass: physical and chemical properties of particle-phase emissions, Atmos. Environ., 39, 6747-6764, 2005.

Haywood, J. M. and Shine, K. P.: The effect of anthropogenic sulfate and soot aerosol on the clear sky planetary radiation budget, Geophys. Res. Lett., 22, 603-606, doi:10.1029/95GL00075, 1995.

He, Z., Kim, Y. J., Ogunjobi, K. O., and Hong, C. S.: Characteristics of $\mathrm{PM}_{2.5}$ species and long-range transport of air masses at Taean background station, South Korea, Atmos. Environ., 37, 219-230, doi:10.1016/S1352-2310(02)00834-8, 2003.

Jenkins, B. M. and Bhatnagar, A. P.: On the electric-power potential from paddy straw in the Punjab and the optimal size of the powergeneration station, Bioresource, 37, 35-41, 1991.

Jung, J., Lee, H., Kim, Y. J., Liu, X., Zhang, Y., Gu, J., and Fan, S.: Aerosol chemistry and the effect of aerosol water content on visibility impairment and radiative forcing in Guangzhou during the 2006 Pearl River Delta campaign, J. Environ. Manage., 90, 3231-3244, doi:10.1016/j.jenvman.2009.04.021, 2009a.

Kadam, K. L., Forrest, L. H., and Jacobson, W. A.: Rice straw as a lignocellulosic resource: collection, processing, transportation, and environmental aspects, Biomass Bioenergy, 18, 369-389, 2000.

Keshtkar, H. and Ashbaugh, L. L.: Size distribution of polycyclic aromatic hydrocarbon particulate emission factors from agricultural burning, Atmos. Environ., 41, 2729-2739, 2007.

Kim, K. W., Kim, Y. J., and Oh, S. J.: Visibility impairment during yellow sand periods in the urban atmosphere of Kwangju, Korea, Atmos. Environ., 35, 5157-5167, doi:10.1016/S13522310(01)00330-2, 2001.

Kim, Y. J., Kim, M. J. Lee, K. H., and Park, S. S.: Investigation of carbon pollution episodes using semi-continuous instrument in Incheon, Korea, Atmos. Environ., 40, 4064-4075, doi:10.1016/j.atmosenv.2006.03.028, 2006.
Lee, K. H., Kim, Y. J., and Kim, M. J.: Characteristics of aerosol observed during two severe haze events over Korea in June and October 2004, Atmos. Environ., 40, 5146-5155, doi:10.1016/j.atmosenv.2006.03.050, 2006.

Lee, M., Song, M., Moon, K. J., Han, J. S., Lee, G., and Kim, K.R.: Origins and chemical characteristics of fine aerosols during the northeastern Asia regional experiment (Atmospheric Brown Cloud-East Asia Regional Experiment 2005), J. Geophys. Res., 112, D22S29, doi:10.1029/2006JD008210, 2007.

Malm, W. C. and Hand, J. L.: An examination of the physical and optical properties of aerosols collected in the IMPROVE program, Atmos. Environ., 41, 3407-3427, doi:10.1016/j.atmosenv.2006.12.012, 2007.

Ortiz de Zárate, I., Ezcurra, A., Lacaux, J. P., and Dinh, P. V.: Emission factor estimates of cereal waste burning in Spain, Atmos. Environ., 34, 3183-3193, 2000.

Pitchford, M., Malm, W., Schichtel, B., Kumar, N., Lowenthal, D., and Hand, J.: Revised algorithm for estimating light extinction from IMPROVE particle speciation data, J. Air Waste Manage. Assoc., 57, 1326-1336, doi:10.3155/1047-3289.57.11.1326, 2007.

Ramanathan, V., Crutzen, P. J., Kiehl, J. T., and Rosenfeld, D.: Aerosols, climate, and the hydrological cycle, Science, 294, 2119-2124, doi:10.1126/science.1064034, 2001.

Streets, D. G., Bond, T. C., Carmichael, G. R., Fernandes, S. D., Fu, Q., He, D., Klimont, Z., Nelson, S. M., Tsai, N. Y., Wang, M. Q., Woo, J. H., and Yarber, K. F.: An inventory of gaseous and primary aerosol emissions in Asia in the year 2000, J. Geophys. Res., 108, 8809, doi:10.1029/2002JD003093, 2003.

US EPA: Emission Factor: Documentation for AP-42, Open Burning, Office of Air Quality Planning and Standards and Office of Air and Radiation (Ed.), AP-42 Database, U.S. Environmental Protection Agency, North Carolina, 34 p., 1992.

White, W. H.: Reduction of visibility by sulphates in photochemical smog, Nature, 264, 735-736, doi:10.1038/264735a0, 1976.

Yoon, S.-C. and Kim, J.: Influences of relative humidity on aerosol optical properties and aerosol radiative forcing during ACE-Asia, Atmos. Environ., 40, 4328-4338, doi:10.1016/j.atmosenv.2006.03.036, 2006. 